\title{
The Gendering of Irish and Caribbean Food/Land Crises in Children's Novels by Marita Conlon-McKenna and James Berry
}

\section{Kate Houlden and Sorcha Gunne}

Barbadian historian Hilary Beckles has highlighted the persistent characterization of the Irish in colonial literature as 'one-dimensional colonial characters ... battered and bruised by a triumphant imperial Englishness that viewed them as "baggage” along the route from Cork and Limerick through Bristol to Boston and Barbados', words that draw attention to the interlinked colonial histories of Ireland and the Caribbean. ${ }^{1}$ The former's role in supporting the imperial endeavour notwithstanding, both locales were, in the nineteenth century, sites of peripheral agricultural production, Ireland serving as Britain’s ‘breadbasket’ (producing meat, vegetables, grain, and alcohol for the British market) and the Caribbean providing 'exotic’ commodities for export world-wide. ${ }^{2}$ In the case of the latter, the system was maintained by slave labour, whereas in Ireland, wealthy English landlords presided over a system of tenant farming that Marx characterized as 'rackrenting', which engendered extreme

\footnotetext{
${ }^{1}$ Hilary McD. Beckles, 'Foreword: Irish Routes,' in Caribbean Irish Connections: Interdisciplinary Perspectives, ed. by Alison Donnell, Maria McGarrity and Evelyn O'Callaghan (Kingston, Jamaica: University of the West Indies Press, 2015), ix-xi, p.ix.

${ }^{2}$ Christine Kinealy, The Great Irish Famine: Impact, Ideology and Rebellion (Basingstoke: Palgrave, 2002), p.112-113.
} 
poverty; ${ }^{3}$ both sites, therefore, suffered under extractivist colonialist-capitalist regimes. Despite this, recognition that Transatlantic Slavery and the Famine in Ireland alike occurred because of wider global economic conditions has been lacking, with little sustained analysis (with few exceptions) of each region from a world-systems perspective. ${ }^{4}$ Expanding on our sense of Ireland and the Caribbean as being jointly

${ }^{3}$ See Eamonn Slater, 'Marx on Ireland: The Dialectics of Colonialism,' NIRSA Working Paper Series 73 (2003), p.36, p.50-55.

${ }^{4}$ See Eric Vanhaute, 'From Famine to Food Crisis: What History Can Teach us about Local and Global Subsistence Crises’, The Journal of Peasant Studies 38.1 (2011), 47-65; more generally, Denis O’Hearn, The Atlantic Economy: Britain, the US and Ireland, (Manchester: Manchester UP, 2001) and Journal of World-Systems Research, Special Issue: Ireland in the World-System 22.10 (2016) ed. by Aidan Beatty, Maurice Coakley, and Sharae Deckard; and on emigration, Jim Mac Laughlin, 'Emigration and the Peripheralization of Ireland in the Global Economy', Review (Fernand Braudel Center) 17.2 (1994), 243-273 with regard to Ireland. Caribbean slavery has more commonly been read in light of the Atlantic economy, although see also Immanuel Wallerstein, ‘The Caribbean and the World-System’; Caribbean Dialogue (Sir Arthur Lewis Institute of Social and Economic Studies) 8.3 (2002), 15-30; and Steve J. Stern, 'Feudalism, Capitalism, and the World-System in the Perspective of Latin America and the Caribbean', The American Historical Review 93.4 (Oct 1988), 829-872; in literary contexts, see Chris Campbell and Michael Niblett, The Caribbean: Aesthetics, World-Ecology, Politics (Liverpool: Liverpool University Press, 2016); Kerstin Oloff and Michael Niblett (eds.) Perspectives on the 'Other America': Comparative Approaches to Caribbean and Latin American Culture (Amsterdam: Rodopi, 2009). 
tethered to global imperial trends, we seek to emphasize what Claire Westall calls 'readings of texts in relation to the multiform violence of (often resource-determined) incorporation into the world-system'. ${ }^{5}$

To do so, this essay contrasts two children's novels, Under the Hawthorn Tree (1990) by Marita Conlon-McKenna, and Ajeemah and His Son (1991) by James Berry, investigating their respective portrayals of world-ecological concerns in Ireland and Jamaica, specifically their depiction of the foundational regional crises of the Irish potato Famine and transatlantic slavery. Children’s fiction proves fertile grounds for such analysis because, as Carolyn Daniel contends, it 'is a largely underutilized source of historically relevant information about the intimate details of everyday life', a sentiment that indicates its potential value in disrupting the primary claims of regional canons that tend either to under-represent food crisis (in the case of Ireland) or offer a crowded field (with regard to literary depictions of Caribbean slavery). ${ }^{6}$ Notably, both novels use historical fictive modes to give a profound sense of what Raymond Williams’ calls the ‘structure of feeling' associated with a particular society and culture in a given period, the 'particular living result of all the elements in the general organization'. ${ }^{7}$ Moreover, the apparent simplicity of their register and their shared use of child-like forms work to disarm readers, reflecting both the irreality, and the glaring inequality, of integration into global markets.

${ }^{5}$ Claire Westall, 'World-Literary Resources and Energetic Materialism', Journal of Postcolonial Writing 53.3 (2017), 265-276, p.271.

${ }^{6}$ Carolyn Daniel, Voracious Children: Who Eats Whom in Children's Literature (New York: Routledge, 2006).

${ }^{7}$ Raymond Williams, The Long Revolution (Ontario: Broadview Press, 2001), p.64. 
Spanning 1807-40, Berry's Ajeemah tells the story of the eponymous Ajeemah and his offspring, Atu. As father and son travel across an unidentified West African locale to pay a dowry to the family of Atu's intended bride, they are attacked by kidnappers. Torn from kin, culture, and home, they are forced onto a slave ship and transported to Jamaica where they are separated and sold to different plantations never to see each other again. Whereas Atu eventually commits suicide after a series of rebellious acts, his father's initially mutinous feelings are quelled by the gendered consolation of his relationship with a fellow slave, and by the comparable solace of his eventual conscription into the heteronormative and land-owning principles of the island's emergent peasant class. If Ajeemah is unusual within the wider pantheon of Caribbean writing about slavery for Berry's willingness to indict his protagonist's conformity to the norms undergirding capitalist expansion, Conlon-McKenna’s Hawthorn Tree is significant because, as Karen Hill McNamara notes, it was 'the first Irish Famine book published for children in Ireland ... 140 years after the catastrophe'. ${ }^{8}$ Set during the 1840s, in the second year of the Famine, with analeptical episodes recalling how the potato crop failed, the novel focuses on three children: siblings Eily, Michael and Peggy O’Driscoll. Initially, it depicts the hardships of family life in Duneen during the Famine, but after their parents are forced to leave and do not return, the children embark on a journey to escape the workhouse and find their long-lost great aunts. This expedition takes the form of a standard quest narrative and is characterized predominantly by the children's food gathering needs.

\footnotetext{
8 Karen Hill McNamara, 'Potato Eaters: Food Collection in Irish Famine Literature for Children', in Critical Approaches to Food in Children’s Literature, ed. by Kara K. Keeling and Scott T. Pollard (New York: Routledge, 2009), 149-166, p.155.
} 
In Ajeemah, Berry reaches beyond the novel's localized specificity to demonstrate how, despite its horrors, the slave trade forcibly made Africans into 'Caribbean people and Americans' ${ }^{9}$ Hawthorn Tree, meanwhile, contributes a similarly globalized perspective, as exemplified by one character's recognition that Ireland's Famine is not an isolated incident, but a consequence of a 'world [that] has gone crazy' ${ }^{10}$ This essay, therefore, maps the correspondences between their portrayals of food regimes and crises in relation to the larger world-ecology, in keeping with Michael Niblett’s interest in 'a comparative model of literary study' that 'holds out the possibility of detecting likenesses (and likenesses of the unlike)' between different locales 'as they respond to the same - yet differently articulated world-historical forces of capitalist modernity'. ${ }^{11}$

In using the term world-ecology, we follow Jason W. Moore's critique of how capitalism has created 'external natures as objects to be mapped, quantified and regulated so that they may service capital's insatiable demands'. ${ }^{12}$ In contrast, and moving away from this 'narrative trope of “the” environment (as object)', Moore favours a notion of 'environment-making (as process), at all turns a co-production of

9 James Berry, Ajeemah and His Son (New York: Harper Trophy, 1994), p.3. Hereafter cited parenthetically.

10 Marita Conlon-McKenna, Under the Hawthorn Tree (Dublin: O’Brien Press, 1990), p.38. Hereafter cited parenthetically.

${ }^{11}$ Michael Niblett, 'World-Economy, World-Ecology, World Literature’, Green Letters: Studies in Ecocriticism 16.1 (2012), 15-30, p.16.

12 Jason W. Moore, 'Technics and Historical Nature: Praxis of the Capitalist WorldEcology’, 28 March 2014 <https://jasonwmoore.wordpress.com/2014/03/.> [accessed 01 March 2018], npag. 
specifically bundled human and extra-human natures'. ${ }^{13}$ Accordingly, we are interested in the ways that Berry and Conlon-McKenna reveal socio-ecological formations being reshaped through their incorporation into the world-system, their shared publication in the early 1990s proving coterminous with the increased entrenchment (and recognition) of a neoliberal world order and gesturing perhaps, towards a heightened public understanding of the role played by food regimes in contemporaneous political and economic systems. Specifically, Ajeemah shows sustenance being used as disciplinary tool, in accordance with Mike Davis’s claim that starvation is only one 'part of a continuum with the silent violence of malnutrition that precedes and conditions it', while throughout Hawthorn Tree, famine is marshalled as an overt tactic in the forced integration of non-capitalist peasants into the world market, in keeping with Davis's further statement that, in contexts such as nineteenth century India: ““Millions die” was ultimately a policy choice'. ${ }^{14}$ The theme of food therefore offers the opportunity to make systemic inequalities comprehensible, and imaginable, to children.

Depictions of land and food production have long been gendered, acutely so in colonial contexts. ${ }^{15}$ Notably, it is when Ajeemah enters into a heterosexual relationship that his desire for land ownership is accentuated, whereas Hawthorn Tree repeatedly contrasts the policed lands of the patriarchal estate with wilder, border territory - which is itself linked to (female) folk knowledges and subsistence food-

\footnotetext{
13 Moore, npag.
}

14 Mike Davis, Late Victorian Holocausts: El Niño Famines and the Making of the Third World (London: Verso, 2001), p.21, p.11. See also Kinealy, p.116. 15 See, for example, Anne McClintock, Imperial Leather: Race, Gender, and Sexuality in the Colonial Contest (New York: Routledge, 1995). 
gathering. Much as natural resources have been mined extensively throughout colonialist-capitalist history, so too, women's labour, particularly in the sphere of social reproduction, has similarly been extracted. Both our chosen texts commence with a traditional family (labour) unit being broken by an enforced journey, before culminating with a reconfigured or proxy family, which works to shore up extractivist heteropatriarchal capitalism at the same time as it illustrates the interconnected exploitation of what Maria Mies labels 'women, nature and colonies'. ${ }^{16}$ To this trio, we might add the role of children - both in terms of domestic labour (as demonstrated by Conlon-McKenna) and with regard to patriarchal inheritance (as revealed by Ajeemah's insistence on the linkage of land and reproduction) - thereby connecting both gender and genre to our broader concern with environment-shaping as socioecological process.

First, we discuss the Caribbean, then the Irish consequences of worldsystemic integration, making clear how our chosen texts illustrate such trends. Next, we address both novels' formal registration of world-literary disparity, exploring their use of childish modes in greater detail and making a case for their shared use of gothic forms (particularly vampires and zombies) to illustrate the ecological and social horrors of capitalist expansion. Finally, the essay closes with our reflections on the gendered significance of how Berry and Conlon-McKenna redomesticate their protagonists in the service of extractivist heteropatriarchal capitalism.

\footnotetext{
${ }^{16}$ Maria Mies, Patriarchy and Accumulation on a World Scale: Women in the International Division of Labour (London: Zed Books, 1986).
} 


\section{The Re-Ordering of Caribbean Landscapes and Lives}

Bonham C. Richardson makes clear that Caribbean slavery was 'a global, not a regional, enterprise', as illustrated by the fact that

[T]he original domestication site of the principle cash crop (sugar cane) probably was southern Asia; the labor supply and some food crops were of West African origin; building materials, livestock, and food came from eastern North America; and the capital, managerial experience, and technology were from western and southern Europe. ${ }^{17}$

More specifically, 'in combining field and factory at an early date', the Caribbean plantation 'was perhaps “industrial” prior to the rise of industry in Europe', words marking the region's importance to capitalist world-systemic development. ${ }^{18}$ These close links with 'the European and, later, North American-centered world-economy' mean that the Caribbean has frequently borne the brunt of 'the innumerable and often damaging effects of international capitalism's advances and retreats, swings in commodity prices, and resultant booms and busts' ${ }^{19}$ Land was always crucial to such processes since, as Sidney Mintz (2009) speculates, the entire system of slavery was, in part, a consequence of there being ample land for colonization, but a scarcity of labour. He elaborates: ‘[s]lavery provides the entrepreneur with a guaranteed, controllable, and disciplined labor force' in an environment where 'the decimation of

17 Bonham C. Richardson, The Caribbean in the Wider World, 1492-1992: A Regional Geography (Cambridge: Cambridge University Press, 1998), p.38. 18 Richardson, p.40.

${ }^{19}$ Richardson, p.4. 
native populations had left empty lands'. ${ }^{20}$ Plantation owners had ultimate responsibility for feeding this labour force, a process skewed by tensions between the high cost of (weather dependent) food imports, the prioritization of the most fertile land for sugar cane, and the need to furnish slaves with some opportunity for subsistence farming in order to maintain food reserves. Mintz spells out how, in the eighteenth and nineteenth centuries, disruption to food importation often led to 'a vicious circle of high prices, malnutrition, and reduced production and profits'. ${ }^{21}$ Factors such as these feed directly into Sylvia Wynter’s discussion of the crucial difference, and dual relation between, what she terms 'plot and plantation' - the former slave-tended lands constituting 'the focus of resistance to the market system and market values' in contrast to the latter, which served as catastrophic, external imposition. ${ }^{22}$ With Emancipation on the horizon in 1838, however, plantation owners were faced with the prospect of being unable to replenish their labour force, which, unsurprisingly, was eager to flee the estates. Those enslaved who had garnered enough liquid capital through pre-Emancipation agricultural practices and island trading to purchase their own land were able to assure their entry into a newly developing peasant class. The bulk of Jamaica’s population, however, were left

20 Sidney W. Mintz, Caribbean Transformations (New Brunswick and London: Aldine Transaction, 2009), p.65.

${ }^{21}$ Mintz, p.181.

22 Sylvia Wynter, ‘Novel and History, Plot and Plantation’, Savacou 5 (June 1971), 95-102, p.99. 
'mired in poverty, with little capital to purchase land, and unable to meet the high fees required to exercise their voting franchise'. ${ }^{23}$

Ajeemah opens with a clear-eyed recognition of the broader economic issues undergirding Caribbean realities, in keeping with Niblett's assertion that worldliterature will, ‘at some level ... bear the impress of the structural totality’ of the world-system. ${ }^{24}$ As early as the novel's first pages, Berry asserts that slavery was about the creation of 'a free labor force' geared towards the plantation owners' 'money-making' (p.4), which necessitated enslaved populations emptying 'their work lives into other people’s bank accounts' (p.79). The coercive role played by food is also fully evident. The first night of their kidnapping, father and son are given only 'tiny bits of food and very little to drink' in combined attempt to keep costs down and break their spirits (p.13). Once arriving in the Caribbean, seasoned slave Quaco-Sam advises Ajeemah to accept his lot, assuring him: 'you get you once-a-week piece a meat or saltfish; you get you plot a land to grow you own food; you have nothin'; but you get used to it' (p.31). This conformist message makes clear that the protagonist's survival will now be dependent on a mixture of food provided and food farmed. The fact that this is the first piece of advice he receives highlights the new importance of food-getting to his existence, in contrast to the easily accessible 'fields of yam and grain growing robustly' back home (p.5). One can see why it is, therefore, that Ajeemah feels that 'this New World business attacked him as a person. Attacked him

${ }^{23}$ Lizabeth Paravisini-Gebert, 'American Landscapes and Erasures', in Perspectives on the 'other America': Comparative Approaches to Caribbean and Latin American Culture, ed. by Michael Niblett and Kerstin Oloff (Amsterdam: Rodopi, 2009), 73102, pp.78-79.

24 Niblett, p.19. 
as a way of life!' (p.41). These words instantiate Niblett's assertion that the Caribbean experience of slavery, particularly its 'ecological regimes and revolutions', reorganized 'in fundamental ways the material conditions, social modalities, and areas of experience' of those unfortunate enough to be caught up in it. ${ }^{25}$ They also gesture towards the ways in which individual (bodily) experience becomes integrated into structures of power, reflecting Marx's emphasis on 'the muscles, nerves, bones, and brains' of labourers as well as the labour-power they produce. ${ }^{26}$ Acquiescent figures, like Quaco-Sam, are shown to be rewarded, receiving 'special gifts of sugar and rum' for informing on fellow slaves - these, notably, being the very same goods exported for consumption in the core by those constructed as their racial superiors (p.29).

Berry also gives a strong sense of the ecological transformations wrought by the plantation system and its nascent industrialization, revealing the 'radical transformation of the global environment' brought about by the 'globalizing propensities of the capitalist world-system': ${ }^{27}$

The estate kept up the loudest and most urgent combined noises on the tropical landscape. The estate workshops contrasted clangings and hammerings, wood sawings, animal voices and songs of slaves working. In the vast lakelike fields of sugar-cane, cowhide whips cracked on the backs of work animals and black people washed in sweat. Wheels of cane-laden wagons churned up their field tracks, up to the work yard, where the sugar-making furnaces roared. And

25 Niblett, p.20.

${ }^{26}$ Karl Marx, Capital, A Critique of Political Economy: Volume 1, trans. by Ben Fowkes (London: Penguin, 1990), p.717.

27 Niblett, p.15. 
piled-up barrels of sugar, like the piled-up casks of rum, were rolled out and taken away to the wharves. And all of this was the tune of big profits (p.44).

Here, Berry highlights how the 'tropical landscape' is transformed. The aggression of words like 'clanging', 'hammering', 'cracked', and 'churned' enact the violence with which Jamaica's terrain was shaped to meet outside needs - in sensory echo of 'the Caribbean's violent integration into the capitalist world-ecology'. ${ }^{28}$ The whips striking ‘the backs of work animals and black people’ alike illustrate Harriet Friedmann's claim that hierarchies of control over territory, domestic species and specific humans led to the notion amongst elites that 'foodgetting was an aspect of lower animal nature'. ${ }^{29}$ Equally, 'wharves' and the repeated mention of 'piled-up' goods reflect the plantation’s crucial role in supplying international markets, demonstrating how 'agriculture and food have all along invisibly underpinned relations of property and power in the world system'. ${ }^{30}$ Traces of the enslaved's previous lives still linger, however. The poignantly brief 'songs' gestures towards residual folk cultures - as well as W. E. B. Du Bois's account of the 'sorrow songs' of the enslaved ${ }^{31}$ - while the oddly naturalistic description of cane fields as 'lakelike'

28 Campbell and Niblett, p.9.

${ }^{29}$ Harriet Friedmann, 'What on Earth is the Modern World-System? Foodgetting and Territory in the Modern Era and Beyond', Journal of World-System Research 1.2 (Summer/Fall 2000), 480-515, p.481.

${ }^{30}$ Harriet Friedmann, 'Feeding the Empire: The Pathologies of Globalized Agriculture', in The Empire Reloaded: Socialist Register, ed. by Colin Leys and Leo Panitch (London: Merlin, 2005), 124-143, p.124.

31 W. E. B. Du Bois, The Souls of Black Folk (Chicago: Dover Thrift Editions, 1994). 
hints at older, rural patterns of life. 'Combined', in the first sentence, then, serves as implicit nod to the combined and uneven socio-ecological relations undergirding this reordering of both landscape and lives.

At the same time, the practical effects of Emancipation are already in evidence. Berry makes clear that the estate owners are 'furious at the idea of an end to their regular supply of a free labor force', grinding their teeth 'in fury and rage at the coming end of their money-making' (p.4). As this suggests, he does not shy away from invoking the plantation classes' emotional response to this change, their 'wild rage, resistance and awful reactions' being granted an ironic cast in light of the very real suffering Ajeemah and his son experience (p.3). Determined to circumvent the system, these privileged elites resolve ‘to beat that end-of-slave-trade deadline’ by getting and supplying 'as many more slaves as they could in the short time left' (p.4), while it is also made clear that, once slavery ends, they 'received twenty million pounds from the British government' in compensation for their 'loss of property' (p.79). This information sits awkwardly against Eric Williams's notorious contention that the plantation system was at the beginning of a period of economic decline in the early nineteenth century, as well as later scholarship arguing that a faltering sugar economy fed into the success of the Abolitionist cause. ${ }^{32}$ Nevertheless, it does give a sense of elite, white anxiety as one established way of life (and structure of domination) morphed into newer coercive forms. This vexed relationship between humanitarian realities and economic imperatives applies equally to nineteenth century Ireland as we illustrate next.

32 Eric Williams, Capitalism and Slavery (Chapel Hill: The University of North Carolina Press, 1994); David Beck Ryden, West Indian Slavery and British Abolition, 1783-1807 (Cambridge: Cambridge University Press, 2009). 


\section{Ireland as Bread Basket for the British Imperial Centre}

The Irish Famine - sometimes called the Potato Famine, the Great Hunger, or An

Górta Mór, in Irish - was 'one of the most devastating food crises in world history'. ${ }^{33}$ It happened because, although Irish farmers produced many crops for export, the local population relied almost entirely on potatoes for sustenance. As Maurice Coakley therefore asserts, the Famine was a consequence of Ireland's peripheral integration in an unequal world-system:

[P]oor harvests were greatly exacerbated by the commercialisation of agriculture which imposed systemic pressure to produce cash crops and reduce crop diversity ... food was exported to cover rent and taxes while peasants starved ... colonial administrations were very reluctant to admit that there was a serious famine, or to spend state money to ameliorate it. Famine relief was hampered by concern not to distort the working of the free market ... The

33 Eric Vanhaute, Richard Paping and Cormac O’Gráda, When the Potato Failed: Causes and Effects of the Last European Subsistence Crisis, 1845-1850, (Turnhout, Belgium: Brepols, 2007), p.55. As Vanhaute et al explain, the Famine was responsible for approximately one million people emigrating and the deaths of another million 'or one-eighth of the total population ... Most of the victims were the rural poor ... The demographic impact of sudden economic shocks such as famines becomes not only visible in a sudden rise in mortality, but also in a decline in fertility and natality. In Ireland births fell back by a third ... [Furthermore,] absentee Anglo-Irish landlords were mostly preoccupied by their own survival, often resulting in campaigns of mass eviction and weak support for local relief structures' (pp.26-31). 
governments were slow to 'give away' food, instead it had to be worked for. In Ireland in the 1840s, the destitute had the option of workhouses (if there was space) where families were broken up. ${ }^{34}$

Similarly, Christine Kinealy maintains that ' $\mathrm{t}$ ] he Irish poor did not starve because there was an inadequate supply of food within the country, they starved because political, commercial and individual greed was given priority over the saving of lives'. ${ }^{35}$ A world-ecological approach, in particular, draws attention to the fact that, despite there being a European-wide crop failure, it was only Ireland that suffered such catastrophic effects. In a broader sense, therefore, understanding the Irish Famine as a food crisis caused by the uneven development of a peripheral or semiperipheral site has profound implications for understanding contemporary food catastrophes because, as Vanhaute et al argue, 'social and ecological crisis of the capitalist world-system, forces us to rethink the traditional, dualistic perception of peasants in the modern world' thus countering the flawed perception of famine as a relic of the past that is characteristic of modernization theory. ${ }^{36}$

Like Ajeemah and His Son, Under the Hawthorn Tree demonstrates an understanding of how global economic forces play out in what Frederic Jameson frames as one 'concrete situation'. ${ }^{37}$ Hill McNamara maintains that the text stands as

${ }^{34}$ Maurice Coakley, Ireland in the World Order: A History of Uneven Development (London: Pluto, 2012), 56\%, kindle edition.

35 Kinealy, p.116.

36 Vanhaute et al, p.62.

37 Fredric Jameson, 'Third-World Literature in the Era of Multinational Capitalism', Social Text 15 (1986), 65-88, p.86. 
a corrective, countering the 'notion that Irish peasants were somehow responsible for the consequences of the Famine due to their reliance on the potato' and showing how 'the Irish land system helped create this dependence'. ${ }^{38}$ The peculiarities of this apparatus are illustrated by Conlon-McKenna’s repeated, and innocent-sounding, references to 'yellow meal' (p.15, p.37). As Kinealy notes, government policy in dealing with the Irish Famine was to import cheap corn from India, which, 'although not sufficient to feed the distressed, was successful in stabilizing the price and distribution of corn' internationally. ${ }^{39}$ Its importation was 'not for the purpose of meeting the entire wants of the Irish people, but for the purpose of checking the markets and of preventing the price of corn from being unduly enhanced'. ${ }^{40}$ ConlonMcKenna's allusions thus recall Moore’s thesis that capitalist accumulation 'unfolded through a greatly expanded ecological surplus, manifested in cheap food, cheap energy and cheap inputs' ${ }^{41}$ Or, as Niblett puts it, things 'are “cheap” to the degree that they drive down the system-wide organic composition of capital ... Cheap food, moreover, reduces the value of labour-power' ${ }^{42}$

Ireland's role as agricultural producer for the British imperial centre is most explicit in the text when the children reach the port town of Ballycarbery. There, they are struck by how, despite 'filthy beggars roam[ing] the streets', the roads 'were

38 Hill McNamara, p.161.

${ }^{39}$ Kinealy, p.102.

40 Kinealy, p.103.

41 Jason W. Moore, 'The End of the Road? Agricultural Revolutions in the Capitalist World-Ecology, 1450-2010,’ Journal of Agrarian Change 10.3 (July 2010), 389-413, p.392.

42 Niblett, p.18. 
thronged. Maybe it was a market day! ... normal business was taking place. There did not seem to be much sign of shortage there' (pp.100-101). In stark contrast to their mother's account of going to town and scrounging for imported corn earlier in the novel, here are the signs of affluence - ladies and girls are shopping for fine clothes and hats and sheep and cattle are being auctioned, leaving the children incredulous (p.37, p.101). As the episode unfolds, however, it is soon made clear why there is such abundance:

Suddenly, a great hullabaloo broke out in the main square as five carts slowly approached one after the other in a line. The wooden carts creaked with the heavy weight of their load. They were laden with sacks of grain! Six soldiers appeared out of nowhere and positioned themselves on either side of the caravan as it wound its way forward ... Two boats were tied to the quayside and they moved very gently on the water. A large warehouse lay on one side and from this men were rolling large kegs and barrels to be placed on the boats. One old man got up his courage ... 'Where is that grain being shipped to?' he asked. 'England,' was the curt reply (pp.101-102).

This phrasing echoes Berry’s barrels of rum and sugar. Words like ‘heavy’ and 'laden’ emphasize quantity, while ‘quayside' and 'boats' similarly underscore the extractive capitalism at work. The trauma of this food crisis is inscribed on the bodies of the gathered beggars who are 'starving people, tired and brokenhearted, who had lost everything', 'bent and twisted', ‘wasted away' and 'skeleton-like', in distinction to those loading the boats who are 'big muscular men’ (pp.101-104). ConlonMcKenna explicitly emphasizes the market system undergirding these dynamics as 
the people appeal to the soldiers for food, but are rebuffed with the words: 'These goods are sold and paid for' (p.103). When a man steps forward 'to try to reach a sack of grain ... one of the soldiers gave him a blow and knocked him to the ground' (p.103). A food riot ensues and the children quickly gather as much as they can, retreating with pockets filled with illicit grain (p.104). Referencing historical accounts, this episode consolidates, at a thematic level, how the text renders the systemic causes of the Famine, making clear that world-ecological inequality is at issue - rather than the good Lord's faulty memory as suggested by their mother's earlier plea 'Has the good Lord forgotten us?' (p.38). ${ }^{43}$

\section{The Formal Registration of World-literary Disparity}

Both Ajeemah and Hawthorn Tree display similar formal properties, capitalizing on their child-like modes to give greater insight into the damage done by world-system integration, in keeping with Niblett's claim that: 'we can begin to think about tracking the aesthetic codification of ecological revolutions in different areas of the globe at different points in time'. ${ }^{44}$ Just as Richardson explains that, 'Caribbean landscapes have been landscapes of contrast; the gleaming towers and smoke-stacks of modern estate factories ... within sight of tiny, impoverished dwellings occupied by plantation workers', so too, Denis O’Hearn discerns that, 'Ireland’s resubordination in an unequal free-trade political union with Britain created a dual economy - agrarian

\footnotetext{
43 As Kinealy notes, food riots and '[a]nger at large quantities of food leaving the country and the deployment of a military escort for this purpose [were] noted in the first year of shortages’ (p.95).

${ }^{44}$ Niblett, p.19, italics added.
} 
periphery and industrial semi-periphery'. 45 These fragmented images of worldecological change might be taken as manifestation of the combined and uneven relations haunting both novels, in reflection of a world-system 'in which "local” and “global” come together in conflictual and unsteady flux' ${ }^{46}$ More specifically, the fact that both books are written for children aligns with the Warwick Research Collective's (WReC) interest in those forms of writing with their roots 'in fanciful childhood modes of narration and representation but ... [their] branches in the unforgiving salt air of the present' ${ }^{47}$ Following on from this, we argue that both texts disarm their readers through their seeming simplicity of style, the use of child-like modes, in fact, chiming with the irreality of integration into global markets.

Furthermore, both authors draw out the spectral aspects of their fictional worlds so as to illustrate the horrors of ecological and social change: Ajeemah deploys vampiric imagery to portray its rapacious slave traders and plantation owners, while Hawthorn Tree uses imagery of zombification, in addition to decay and disease, to convey the degradations of famine. These tendencies can be understood in light of WReC's interest in how the realities of combined and uneven development might lead to an abundance of 'gothic and spectral tropes' reflecting 'the abstractions of capital and commodity fetishism'. ${ }^{48}$ Specifically, they emphasize the 'revelatory, irrealist vocabulary’ of Karl Marx’s writing, emphasizing how this is ‘consciously chosen: a

\footnotetext{
${ }^{45}$ Richardson, p.40; O’Hearn, p.25.
}

46 WReC (Warwick Research Collective), Combined and Uneven Development: Towards a New Theory of World-Literature (Liverpool: Liverpool University Press, 2015), p.67.

47 WReC, p.71.

${ }^{48}$ WReC, p.75. 
vocabulary to model a particular order of reality', one 'dripping from head to toe ... with blood and dirt'. ${ }^{49}$ Berry and Conlon-McKenna's representational strategies, therefore, conform to Steven Shaviro’s discussion of those zombified workers who function as 'the "human face” of capitalist monstrosity' in comparison to the vampire who 'grows, not through any productive activity of its own, but by expropriating a surplus generated by the living'. ${ }^{50}$

In Berry's novel, Ajeemah and Atu's first confrontation with their kidnappers, six fellow Africans, is framed as a clash between worlds. Their attackers are armed with the odd combination of 'two guns, two dogs, and knives and sticks' as well as leg shackles, equipment that, in its movement from the unsophisticated through to the industrialized tools of the plantation, echoes the men's own conscription into the violence of enslavement (p.9). In contrast, Ajeemah wears a 'magic-spell amulet' and 'a flamboyant jacket made of the whole skin of an animal', which makes him look 'like a proper local prince'; attire that does little to temper his treatment (pp.9-10). However, some recognition of the potency of his customs is shown by the kidnappers' leader, who warns his companions not to touch the amulet, cautioning that, 'you begin to rot. Every day you wake up a bit more rotten and deformed', words that instil '[h]orror, awe and dread' in his fellow conspirators (pp.10-11). This trepidation is not enough to counteract the lure of money though, meaning the kidnappers simply proceed as planned avoiding the amulet in question. Yet this interlude is noteworthy for the fact that it is slavery's brutal encroachment into the narrative that appears to trigger the entry of such horror - or irreality. More

49 WReC, p.75; Marx, p.926.

50 Steve Shaviro, 'Capitalist Monsters,' Historical Materialism 10.4 (2002), 281-290, p.282. 
specifically, the kidnappers' reaction gestures towards, and anticipates, the terror about to be experienced by those they have subjugated, marking their own uncertainty at perpetuating the degradations of capitalist modernity in such fashion.

These horrors are writ large through the metaphor of consumption, the reader being told of 'a long-standing belief circulating amongst captives that white men bought them to eat', a fear shared by the protagonists who worry that their 'flesh would end up in the flesh of one of the white men' (p.14, p.16). This might not be true in the literal sense, but Berry makes clear the vampiric aspects of the trade they have fallen victim of. Father and son find themselves 'going through the strange business of being oiled up to look clean and shiny for display for sale' as they are 'put on show for the white captains of the waiting ships to come and choose their purchase' (p.13, p.16). The language of 'business', 'sale', and 'purchase' makes clear the economic aspects of the system, although the pair's anxiety at having fallen 'into jaws of monsters' combined with the later 'sun-reddened excited faces of the white-men planters' bearing down 'upon them like hungry wolves' also gives a strong sense of the inhumanity of their new masters (p.17, p.24). Marx's description of the power of 'dead labour, which, vampire-like, lives only by sucking living labour’ appears more than apt in this instance. ${ }^{51}$

The fact that both men depart the ship having 'lost their magic-spell amulets' yet 'didn't even care' further reinforces the extent that they have been torn from one cultural world and thrown into another (p.24). '[L]imping: all sore, still, weak, half dead' as they disembark, they have been made zombies by their cooption into the industrialized processing of human bodies, in keeping with Shaviro's

${ }^{51}$ Marx, p.342. 
characterization of such figures as 'the dregs of humanity'. ${ }^{52}$ Corresponding with this sense of lost individuality, Ajeemah struggles to comprehend his enslavement. 'For a brief moment', we are told, he 'didn't know where he was at all. It was like walking into a little dream and back out again', an experience that only reinforces his 'feeling of the strange, the alien' (p.28). Yet, later, the 'truth of his position as a slave gripped him with chilling horror. It made him feel swallowed by a nasty horrific monster. He was now inside its belly, becoming the flesh of the monster, little by little' (pp.39-40). This expansive progression of ‘monsters' outwards from Ajeemah’s captors to slavery itself illustrates the horror of his individual subordination to a global system. The irreality of his new existence, meanwhile, expresses Niblett's claim that: 'where Caribbean peoples lack autonomous control over the production of nature, and hence over the production of social reality, this reality appears illusory or irreal since it is authored and manipulated by outside powers'. ${ }^{53}$

The horror of the Famine similarly constitutes a formative aspect of Conlon-McKenna's narrative, which functions as a quest - as is often the case with Zombie fiction. ${ }^{54}$ Although the word itself is never mentioned, the narrative is replete with allusions to zombification. This metaphor is apt for a food crisis, as Kerstin Oloff asserts:

\footnotetext{
52 Shaviro, p.288.

53 Niblett, p.22.

$5421^{\text {st }}$ Century examples might include Cormac McCarthy's The Road (2006), MR

Carey’s The Girl With All the Gifts (2014), or Danny Boyle’s 2002 film 28 Days

Later.
} 
[W]hile the zombie is indeed the 'human face' of capitalist monstrosity, it is also an ecological figure, encoding the rift between humans and their natural environment perpetrated by capitalism, an economic system that centrally depends on the 'downgrading or devaluing of nature'. ${ }^{55}$

Specific to Ireland, Stuart McLean documents how historical narratives about the Famine portray the way that '[v]ictims of starvation from the famine years were ... prone to rise and wander'. ${ }^{56}$ As he puts it: 'Not only did the dead rise unbidden from the grave, they also threatened to lay claim to the living ... living and dead were forced into uncomfortable proximity. ${ }^{, 57}$ This transforms into a betwixt and between state, whereby:

[T]he dead were left alongside the living, often for several days at a stretch before the bodies were removed for burial ... This tardiness in the disposal of bodies seemed to point to something more than the overstretching of hospital and burial facilities. It was as though, given the apparent ubiquity of death, it had ceased to be worth distinguishing too clearly between the living, the dead,

${ }^{55}$ Kerstin Oloff, “"Greening” The Zombie: Caribbean Gothic, World-Ecology, and Socio-Ecological Degradation’, Green Letters 16:1 (2012), 31-45, p.31.

56 Stuart McLean, The Event and its Terrors: Ireland, Famine, Modernity (Stanford: Stanford University Press 2004), p.112. See also Lilian Lucy Davidson’s haunting image, 'Burying the Child’ (Ireland’s Great Hunger Museum, Quinnipiac University).

${ }^{57}$ McLean, p.112. 
and those hastening toward death. Even more disturbing was the tendency of those still living to assume the appearance of the dead. ${ }^{58}$

Such accounts recall zombies specifically - as opposed to more general spectres - as they rise from the grave, are both living and dead at one and the same time, and offer the risk of contagion from fever.

From the group who leave Duneen for the workhouse in chapter five, to the warnings about strangers issued by the healer Mary Kate and the children’s mother, to the children's ongoing fear of sickness, Hawthorn Tree resonates with such allusions. It is around the soup kitchen and workhouse, however, that zombie imagery intensifies. When the children approach the soup kitchen, 'Eily could not believe the crowds ... Hundreds of ragged starving people thronged the small main street ... desperate for food', some 'so weak they could not stand, so they sat on the ground' (p.79-80). As Conlon-McKenna writes:

The faces - the faces - she would never forget them. They all had the same look. The checks were sunken, the eyes wide and staring with deep circles underneath, the lips narrow and tight, and in some cases the skin had a yellow tinge. Hunger and sickness had changed these people. Now they were like ghosts ... This must be hell, thought Eily, for once really scared (p.79-80).

These references to the bodily trauma of starvation not only recall Oloff's argument that zombies are 'a key figure for thinking about aesthetics in relation to worldecology', but that the world-ecological significance of zombies lies in the fact that

${ }^{58}$ McLean, p.115. 
'humans are reduced to being bodily vessels for the production of specifically capitalist value (socially necessary labour time)' ${ }^{59}$ In a similar passage, meanwhile, Michael is shocked at the bodies that litter the streets outside the work house where:

Crowds of people were waiting, sleeping on the cobblestones. They could go no further ... They lay in their rags or blankets ... From within the building came constant moaning and crying, and a smell of disease and sickness seemed to fill the air (p.124).

The children also face the threat of fever, Michael's leg becoming infected and the wound seeping yellow and green pus, while Peggy is attacked by a pack of wild dogs, spiking a fever a few days later (p.73, chapters 9 and 13). These illnesses further signal the danger of contagion - not simply starvation but the infectious consequences of extreme deprivation as a result of systemic inequality, corresponding with Moore's contention that: the 'degradation of nature is the degradation of the worker, and occurs only through the degradation of the worker under the law of value'. ${ }^{60}$

59 Oloff, 2012, p.42; Kerstin Oloff, 'Zombies, Gender, and World-Ecology: Gothic Narrative in the Work of Ana Lydia Vega and May', in The Caribbean: Aesthetics, World-Ecology, Politics, ed. by Chris Campbell and Michael Niblett (Liverpool: Liverpool University Press, 2016), 46-62, p.46.

60 Jason W. Moore, ““The Modern World-System” as Environmental History? Ecology and the Rise of Capitalism,' Theory and Society 32.3 (June 2003), 307-377, p. 321. 


\section{Gendered World-Ecology}

In Under the Hawthorn Tree, the healer, Mary Kate is described as a 'toothless' old woman whose filthy cottage is behind tall hedges to offer her visitors privacy when she provides them with ointments and medicines (pp.14-15, see also p.61). After aiding the children's escape from a group bound for the workhouse, she sends them on their journey with both advice and home-made remedies, thus building a picture of a female occult figure, a trope common in Famine literature. ${ }^{61}$ Oloff contends that, in Caribbean texts, the figure of the 'mad' woman complements the zombie in critiquing world-ecological inequality, noting, for example, that 'zombies and madwomen' paired reveal the 'political, social, and environmental violence that is global in nature, but felt with particular virulence in peripheral locations. ${ }^{92}$ The character of Mary Kate therefore appears to introduce gendered concerns to a world-ecological perspective, illustrating Silva Federici’s point that: 'the continuous expulsion of farmers from the land, war and plunder on a world scale, and the degradation of women are necessary conditions for the existence of capitalism' ${ }^{63}$ With her toothless, wizened and dirty appearance, Mary Kate appears to embody this degradation. However, equally, her appearance is accompanied by a sense of occult social capital. She can, therefore, also be read as a figure of resistance to gendered norms and labour, particularly those espoused by the Catholic Church. Her character has rejected beauty norms, marriage, childbearing and housework, but nonetheless maintains a significant position in the community via her skills as a healer. Unfortunately, however, the subversive implications of the occult woman are not wholly

\footnotetext{
61 See McLean, pp.140-141.

62 Oloff, 2016, p.55.

63 Silvia Federici, Caliban and the Witch (Brooklyn: Autonomedia, 2004), p.13.
} 
incorporated into the gender relations underlying the food regimes of plantation Ireland as the possibilities signalled by Mary Kate's non-conformity are not borne out by the rest of the novel. In fact, across both Hawthorn Tree and Ajeemah, it is striking how their clear-sighted economic critique is undermined by a comparable reliance on traditional gendered roles and the very gendered labour that, as Tithi Bhattacharya puts it, 'produces the worker' in the first place. ${ }^{64}$ Ultimately, both texts commence with a traditional family unit, which is broken by an enforced journey, before culminating with a reconfigured or proxy family at the text's close. In short, both books conclude with the continuation of extractivist heteropatriarchal capitalism. In Ajeemah, enslavement is understood as a process of emasculation. Early on, Ajeemah proclaims, 'Oh, how guns, dogs and mighty kingdoms smash up a man! Smash up his manhood and cut up his pride! ... They want to take away my manhood and nationhood and add it to theirs' (p.18). Conceptualizing slavery in gendered terms is significant as it suggests that world-systemic inequality is inherently patriarchal. Yet Ajeemah is eventually persuaded to take part in the system, abandoning his dream of returning home and instead purchasing his own freedom after he strikes up a relationship with ambitious fellow slave, Bella, who works in the Great House. Their dynamic is explicitly nourished by food as it begins with Bella bringing him ‘a piece a Great House cake. An’ some milk with honey’ (p.77). ‘Once he felt and began to enjoy a wonderful new sense of partnership’, Berry tells us, Ajeemah 'desperately wanted to secure a way to get his own land' (p.77). This refrain is repeated time and again, Bella sharing (and even exceeding) his determination to 'win ways to get land' (p.78). Such principles are passed on to the subsequent

64 Tithi Bhattacharya, Social Reproduction Theory: Remapping Class, Recentering Oppression (London: Pluto Press, 2017), p.1. 
generation, when Ajeemah and Bella’s daughter, Sisi is eventually married to collaborator, Quaco-Sam's son and Ajeemah victoriously reveals a stash of gold he has been hiding for thirty-three years. To great acclaim from the wedding guests, he pronounces that the gold will 'buy them own land, an' own house' - words contextualized for the reader by the fact that he is dressed 'like a wealthy estate owner' whilst asserting them (p.80-82).

Similarly, in Hawthorn Tree, the children find their aunts and re-establish a family unit at the novel's close. Throughout, they have recalled how their aunts rejected marriage in favour of commerce, setting up their own shop in Castletaggart. By the time the children find them, however, the business has folded and the women's redomestication seems almost complete. The story ends with the children sitting around the kitchen table eating their fill of 'fresh soda bread and a jar of best plum jam' and 'hot sweet milky tea' (p.147, p.149); imagery that resonates with Ajeemah's cake and milk with honey. This conventional ending is foreshadowed in the novel as the three children maintain heteronormative gendered roles throughout their journey: Eily is repeatedly described as 'the little mother' (she even sacrifices herself to stay with feverish Peggy when Michael goes looking for help and the workhouse), while Michael is often depicted as the provider (p.117). Their desires and fears are also gendered conventionally, as evidenced when Michael confesses that he wants to 'play on a hurling team like the big fellows, and some day learn to ride a horse and maybe even have a place of my own' - activities typically gendered as male - in contrast to Eily's desire for 'a fine wool dress with a lace collar and combs in [her] hair', so that ‘[m]aybe then when I was older I would fall in love and get married like Mother and have babies of my own' (pp.87-88). 
Key to both Ajeemah and Hawthorn Tree is the way in which these gendered trends are tied into sustenance: food both reveals the crises of the worldsystem and, at one and the same time, is deployed in particularly gendered ways to reestablish and shore up that system. Daniel has asserted that:

Food events within children's literature seduce child readers and add flavor and spice to the narrative. They lend aspects of materiality to the text so that mediation is unsuspected. Ultimately, however, as far as their intended audience is concerned, tales about eating or being eaten usual legitimate and bolster cultural rules and misogyny. ${ }^{65}$

Both our chosen texts support this claim: whether it be cake and milk with honey, or soda bread and jam with sweet tea, in these two novels an end to hunger is inseparable from world-ecological crisis as the heteropatriarchal capitalist status quo is restored.

65 Daniel, pp.212-213. 